\title{
Ocena sprawności działania państwa w odniesieniu do skali wydatków publicznych
}

\section{Marta Postuła ${ }^{1}$}

Nadesłany: 17.09.12 | Zaakceptowany do druku: 21.01.13

\begin{abstract}
Abstrakt
Cel: Celem artykułu jest potwierdzenie tezy, że skala wydatkowania środków publicznych nie wpływa na sprawność działania państwa, która w większej skali jest uzależniona od efektywności ich wydatkowania.

Metodologia: Autorka opiera się na przeglądzie literatury, przeprowadzonym na podstawie baz artykułów naukowych, oraz na analizie konkretnych rozwiązań obowiązujących w Unii Europejskiej i krajach członkowskich OECD, odnoszących się do konsolidacji funduszy w kontekście sprawności działania państwa.

Oryginalność: Na bazie analizy przeprowadzonej w artykule autorka dowodzi, że optymalna polityka fiskalna powinna wykorzystywać dobrze dobrane narzędzia pozwalające na osiągnięcie maksymalnie dobrego sposobu gospodarowania środkami publicznymi w danym otoczeniu zewnętrznym i wewnętrznym, w jakim znajduje się dana gospodarka. Czynnikiem decydującym o sprawności państwa (pomijając czynniki pozafinansowe) nie są absolutne i względne rozmiary wydatków publicznych. Poziom sprawności jest uzależniony od struktury tych wydatków oraz procedur związanych zarówno z procesem planowania, realizacji, ewidencji i sprawozdawczości dotyczącej wydatków publicznych, jak i z poziomem systemu oceny efektywności i skuteczności.
\end{abstract}

Słowa kluczowe: sprawność, wydatki publiczne, usługi, kryzys finansowy

\section{Evaluation of the Effectiveness of State Functioning Based on Public Expenditure}

Primary submission: 17.09.12 | Final acceptance: 21.01.13

\begin{abstract}
Purpose: The purpose of this article is to confirm the thesis that the amount of public funds expenditure has no impact on the effectiveness of state functioning, which - to a greater extent - is dependent on the efficiency of these funds. In the article, the author claims that in the case of the European Union there is no explicit evidence concerning the efficiency of public funds in Member States - both on the micro and macro level.

Methodology: A literature review conducted on the basis of collections of academic and scientific articles and an analysis of particular solutions implemented in the European Union and in OECD Member States as well as concerning the consolidation of public funds in the context of the effectiveness of state functioning.

Originality: The author of this work - on the basis of the (performed) analysis presented in the article, explains that the optimal fiscal policy should use appropriately selected tools allowing to achieve the best (optimal) method for the management of public funds, in particular the external and internal position of the economy of the given country. The key factors that decide on the effectiveness (excluding non-financial factors) are neither universal (absolute) nor relative extent of public spending. The author concludes that the level of effectiveness is either dependent on the structure of this spending and procedures connected with public expenditure planning, executing, accounting and reporting processes, or the level (quality) of the effectiveness and efficiency evaluation system.
\end{abstract}

Keywords: effectiveness, public expenditure, services, financial crisis

$$
\text { JEL: H1, H4 }
$$

\footnotetext{
1 Ministerstwo Finansów

Adres do korespondencji: Ministerstwo Finansów, ul. Świętokrzyska 12, 00-916 Warszawa, e-mail: Marta.Postula@mofnet.gov.pl.
} 


\section{Wstęp}

Kryzys gospodarczy, który rozpoczął się w Stanach Zjednoczonych, a następnie przełożył się na sytuację społeczno-gospodarczą na świecie, miał negatywne skutki dla stanu finansów publicznych dużej liczby państw. W krótkim czasie wskaźniki zadłużenia sektora instytucji rządowych i samorządowych w relacji do PKB gwałtownie wzrosły niemal we wszystkich państwach członkowskich UE, przekreślając tym samym niewielką poprawę, jaką osiągnięto w latach przedkryzysowych. W związku z tym w ostatnich latach priorytetem państw członkowskich UE (poza stworzeniem rozwiązania doraźnego, które ma i będzie miało zastosowanie do Grecji, Portugalii i Cypru) było i nadal pozostaje uporządkowanie polityki budżetowej przy jednoczesnym zapewnieniu sprzyjających wzrostowi gospodarczemu strategii politycznych oraz sprawnym uzdrowieniu sektora finansowego w celu wejścia na drogę naprawy gospodarczej. W ramach prowadzonych w tym zakresie działań znaczna ich część opiera się na dążeniu do zwiększenia, bądź utrzymania na obecnym poziomie, sprawności działania państwa, m.in. poprzez podniesienie efektywności wydatkowania środków publicznych. Celem niniejszego artykułu jest potwierdzenie tezy, że skala wydatkowania środków publicznych nie wpływa na sprawność działania państwa, a jest uzależniona od efektywności ich wydatkowania. Podkreślenia wymaga również, że w przypadku Unii Europejskiej brakuje jednoznacznych wytycznych dotyczących efektywności wydatków publicznych w krajach członkowskich - zarówno na poziomie mikro, jak i makro. W związku z tym w artykule dokonano analizy konkretnych rozwiązań obowiązujących w Unii Europejskiej oraz krajach członkowskich OECD, odnoszących się do konsolidacji funduszy w kontekście sprawności działania państwa. Artykuł podzielono na kilka części, w których omówiono sprawność państwa, jej skalę w zależności od poziomu wydatków oraz efektywności wydatkowania środków publicznych.

\section{| Wydatki publiczne a sprawność państwa}

Rozpatrując związek pomiędzy rozmiarami wydatków publicznych a sprawnością działania państwa, należy wspomnieć o funkcjonującym w literaturze ekonomicznej prawie rosnących rozmiarów aktywności państwa Adolfa Wagnera, które po raz pierwszy opublikowane zostało w Niemczech już w 1876 roku. Zależność opisana przez A. Wagnera polega na absolutnym i relatywnym wzroście aktywności państwa przez realizowane zadania wraz ze wzrostem produktu krajowego (Owsiak, 2000, s. 44). Zdaniem Wagnera państwo przejmuje coraz więcej zadań zarówno stare, jak i nowe wykonuje w coraz pełniejszy, jak również bogatszy sposób, dzięki czemu jego absolutne oraz relatywne znaczenie rośnie, a potrzeby obywateli są lepiej zaspokajane. W związku z decentralizacją wykonywania zadań i ich przesunięciem na niższe poziomy administracyjne szczególnym wzrostem charakteryzują się budżety jednostek lokalnych. Prawo Wagnera sformułowane na przełomie XIX i XX wieku poddawane było w kolejnych dziesięcioleciach próbom empirycznej weryfikacji, często na podstawie wieloletnich szeregów czasowych danych wydatkowych dotyczących konkretnych krajów. Wyniki były zróżnicowane - od 
potwierdzających do negujących istnienie zależności (Peacock i Scott, 2000). Niezależnie od badań empirycznych funkcjonuje krytyka na gruncie rozważań teoretycznych. Zasadniczą osią krytyki jest sprzeczność między efektywnością wykorzystania zasobów a osiąganymi celami społecznymi. Zdaniem S. Owsiaka ustalenie optymalnych rozmiarów i struktury wydatków publicznych nie jest możliwe, rozmiary wydatków publicznych uzależnione są od konkretnych warunków i etapu rozwoju, poglądów oraz doktryny na temat roli państwa w funkcjonowaniu gospodarki i społeczeństwa (Owsiak, 2000, s. 109). Granice wydatków powinny być ustalane pragmatycznie z uwzględnieniem ekonomicznego sensu wydatków, który powinien opierać się na administracyjnym mechanizmie alokacji zasobów.

Zarówno wzrost absolutny, jak i relatywny wydatków publicznych nie oznacza automatycznie wzrostu sprawności państwa. Ocena stopnia sprawności państwa, a dokładniej elementów składających się na nią lub zmian w czasie wymaga zastosowania odpowiednich mierników świadczących o efektywności dokonywanych wydatków. Tradycyjnie poza kilkoma wybranymi wskaźnikami makroekonomicznymi (demograficznymi, dotyczącymi usług społecznych, zatrudnienia itp.) dla określenia stanu zaangażowania oraz rozwoju usług publicznych organizowanych przez państwo posługiwano się analizą wielkości nakładów, np. w relacji do PKB, i ich zmianą. Niewątpliwie wielkość wydatków publicznych na poszczególne obszary potrafi mieć istotny i często decydujący wpływ na poziom dostarczanych usług publicznych. Wpływ rozmiarów finansowania na opisane wcześniej poszczególne elementy charakteryzujące sprawne państwo jest jednak mocno zróżnicowany. Interesujące jest dokonanie analizy i wskazanie, w jakim stopniu stan danego obszaru uzależniony jest od wysokości wydatków, a w jakim od czynników pozafinansowych, przede wszystkim stanu kapitału społecznego oraz systemu regulacyjnego. Czy bezpośrednia poprawa stanu państwa wiążę się z rozmiarami wydatków, czy też z wykorzystywanymi procedurami planowania wydatków publicznych, ich realizacji, ewidencji i sprawozdawczości?

Na potrzeby niniejszego artykułu dokonano pewnej analizy we wskazanym zakresie, odnoszącej się krajów OECD. Zgodnie z dostępnymi statystykami rozmiary wydatków publicznych w stosunku do PKB w krajach OECD wynosiły w latach 2008-2010 średnio 43,6\%, przy czym najniższą średnią odnotowano w Korei - 31,5\%, a najwyższą w Danii - 56,2\%. Poziom wydatków zestawiono ze wskaźnikiem efektywności rządzenia stworzonym i wykorzystywanym od 1996 roku w ramach prac badawczych Banku Światowego (Kaufmann i in., 2010). Na ten indeks składają się: percepcja jakości usług publicznych, jakości służby cywilnej, jakości formułowania i wdrażania polityk. Na rysunku 1 zaprezentowano uzyskaną w 2011 roku - na podstawie przeprowadzonych wywiadów - pozycję poszczególnych krajów OECD w rankingu ponad 200 krajów objętych badaniem.

Zestawienie danych o średnich relacjach wydatków dla poszczególnych krajów z ich miejscem w rankingu indeksu efektywności rządzenia nie pozwala na stwierdzenie, że pozycja kraju w tym rankingu jest istotnie uzależniona od rozmiarów wydatków publicznych. Najwyższą efektywnością charakteryzują się państwa zarówno o wysokim (np. Dania), jak i niskim 
Rysunek 1 | Rozmiary wydatków publicznych w relacji do PKB i wskaźnik efektywności rządzenia

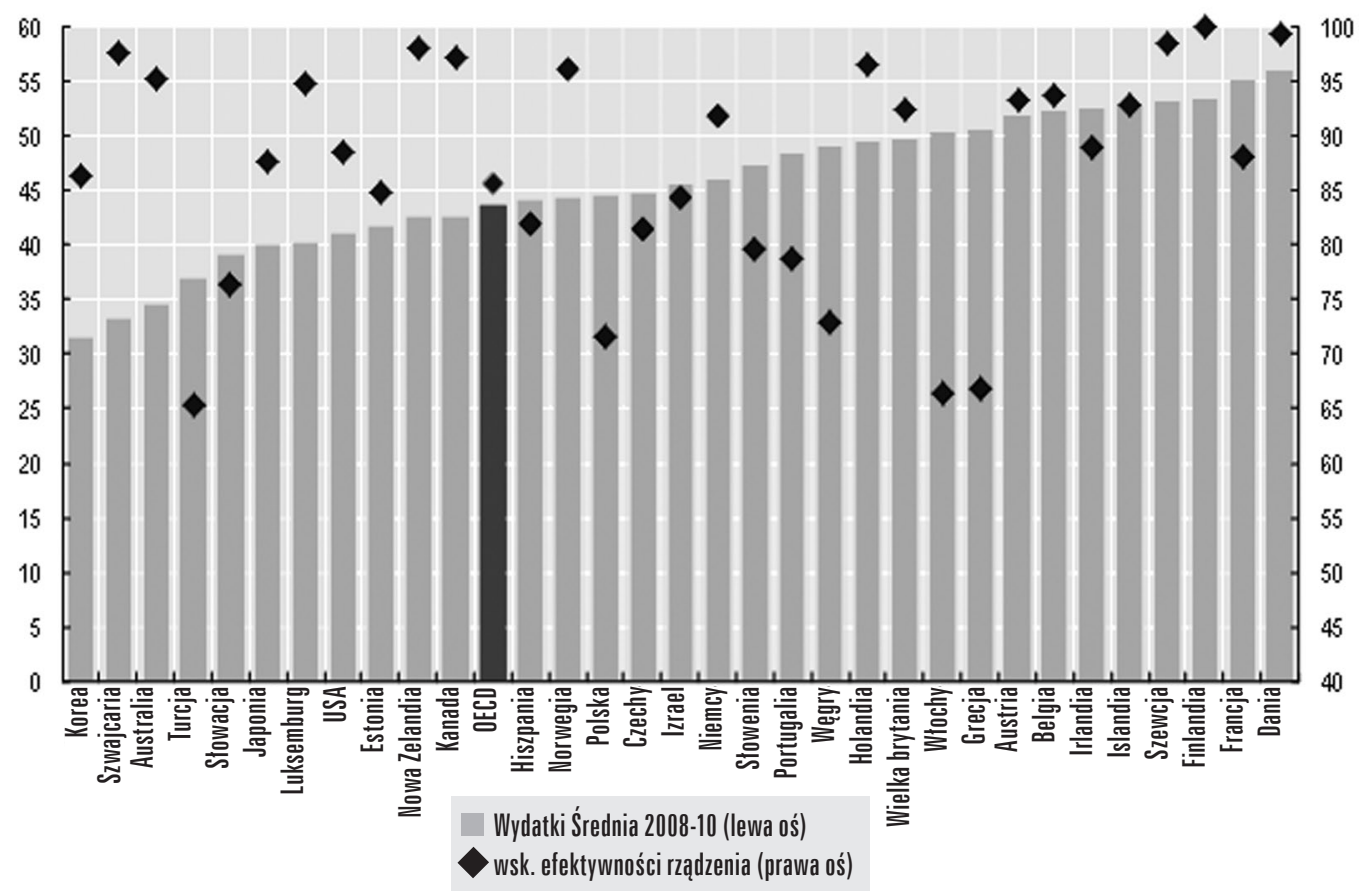

Źródło: OECD Factbook 2011: Economic, Environmental and Social Statistics, Kaufmann i in., The Worldwide Governance Indicators (http://info.worldbank.org/governance/wgi/mc_chart.asp\#).

(np. Szwajcaria) udziale wydatków publicznych w PKB. W związku z powyższym o większej sprawności państwa mogą decydować inne czynniki niż ogólny rozmiar wydatków publicznych, co jest potwierdzeniem tezy postawionej na wstępie artykułu.

Jeśli nie ogólny rozmiar wydatków decyduje o tym, czy państwo działa sprawnie, to należy dokonać oceny pod tym kątem efektywności procesów realizowanych przez administracje publiczne w poszczególnych państwach. Polityka na rzecz poprawy sprawności państwa zasadza się na spełnieniu warunków koniecznych, dotyczących przede wszystkim stabilności finansowej, które nie zawsze są jednak warunkami wystarczającymi. Muszą być one wspomagane spełnieniem warunków jakościowych wpływających bezpośrednio na efektywność.

\section{| Kryzys finansowy a sprawność państw}

Analiza przebiegu sytuacji fiskalnej krajów OECD i Unii Europejskiej w ostatnim dwudziestoleciu pozwala na interesującą dyskusję w sprawie jakości realizowanej przez rządy tych krajów polityki fiskalnej, w kontekście zmian, jakie wywołuje ona w sprawności działania państwa. 
Począwszy od 2009 roku większość krajów członkowskich OECD doprowadziła do znacznego zmniejszenia deficytu sektora finansów publicznych, który w wielu krajach powstał z powodu połączonych skutków kryzysu finansowego i fiskalnego. Średnia poprawa ogólnego deficytu sektora finansów publicznych wyniosła około 2\% PKB w obszarze krajów członkowskich OECD. Część krajów, tj. Węgry, Grecja i Portugalia, a następnie Islandia i Turcja, osiągnęły największą skalę poprawy salda budżetowego. Grecja, Węgry i Portugalia to trzy kraje o najbardziej imponującej skali ulepszeń fiskalnej równowagi, odpowiednio o 6,4, 8,6 i 5,9 punktu procentowego PKB (odpowiednio z deficytów: 15,6\%, 4,5\% i 10,2\%). Natomiast Islandia i Turcja poprawiły salda budżetowe o ponad 4 punkty procentowe w latach 2009-2011.

Jedynym krajem, w którym poziom nierównowagi się pogłębił w tym okresie, była Nowa Zelandia, przede wszystkim ze względu na skutki trzęsienia ziemi w 2010 roku. Japonia i Słowenia także odnotowały niewielki wzrost deficytu budżetowego. Obniżenia poziomu deficytów w latach 2009-2011 nie można wiązać tylko z procesem konsolidacji fiskalnej, w znacznej mierze wynikało z faktu, iż gospodarki w większości krajów OECD odnotowały w tym okresie poprawę koniunktury. Niemcy i Turcja doświadczyły silniejszej poprawy ogólnej równowagi fiskalnej w tym okresie niż przewidywały w swoich w planach konsolidacyjnych.

Wszystkie kraje UE prowadziły autonomiczną politykę fiskalną, poddaną jednak wspólnym rygorom Paktu Stabilności i Wzrostu (PSW), sformułowanego w 1997 roku. Stan finansów publicznych i gospodarki był systematycznie monitorowany oraz oceniany przez niezależne organy unijne. Nie uchroniło to jednak niektórych krajów od kryzysu finansowego, prowadzącego jednocześnie do radykalnego ograniczenia sprawności państwa, wręcz podważającego (np. w Grecji) demokratyczne podstawy tej instytucji. Nie wchodząc w szczegółową analizę funkcjonowania PSW: już same kolejne systematyczne zmiany treści opisujących Pakt dokumentów dokonywane w latach 2000, 2005, 2011 wskazują na nieskuteczność tych regulacji. Ostatecznie dziedzina PSW została zreformowana za pomocą tzw. sześciopaku gospodarczego. Kolejnym dokumentem w tym samym praktycznie zakresie jest umowa międzyrządowa, podpisana w 2012 roku przez 25 krajów UE (oprócz Czech i Wielkiej Brytanii), ustanawiająca Traktat o stabilności koordynacji i zarządzaniu. Ogólny i najbardziej aktualny stan ustaleń dotyczący polityki fiskalnej zawarto w dyrektywie Rady Unii Europejskiej z listopada 2011 roku w sprawie wymogów dla ram budżetowych państw członkowskich, który stanowi praktyczne kompendium rozwiązań stosowanych w budżetowaniu przez kraje o najbardziej zaawansowanych systemach zarządzania finansami publicznymi. Pod pojęciem „ramy budżetowe” rozumiany jest zbiór uzgodnień, procedur, reguł i instytucji stanowiących podstawę prowadzenia polityki budżetowej sektora instytucji rządowych oraz samorządowych. Ramy obejmują zalecenia dotyczące statystyki i rachunkowości, prognoz, numerycznych reguł fiskalnych, średniookresowych reguł fiskalnych oraz przejrzystości finansów publicznych. Propozycje zawarte w dyrektywie pozostają spójne z obszarami reform w finansach publicznych wskazywanych w badaniach prowadzonych przez OECD. W dyrektywie w niedostatecznym stopniu wskazywane są instrumenty dotyczące oceny sprawności działania państwa, a w tym kontekście efektywności i skuteczności wydatków publicznych. Podkreślić należy jednak, że trudno w sposób bezpośredni ocenić efektywność wszystkich wydatków 
publicznych - przykładem na to mogą być wydatki skierowane w okresie kryzysu na wsparcie instytucji finansowych.

Zgodnie z badaniami dokonanymi przez OECD w okresie 2008-2011 konsolidacja fiskalna po stronie wydatkowej dokonywana była głównie w następujących obszarach (OECD, http):

- Wydatki bieżące, które w sposób najbardziej ogólny można zdefiniować jako zmniejszenie wydatków z tytułu tzw. kosztów eksploatacji. Zastosowane w tym przypadku metody obejmują redukcje płac lub personelu, zmiany organizacyjne na poziomie rządowym.

- Wydatki na realizację programów obszarowych, zdefiniowane według klasyfikacji funkcjonalnej OECD dotyczącej rachunków narodowych. Zgodnie z tą klasyfikacją obejmują one m.in. opiekę zdrowotną, system świadczeń socjalnych, emerytury, infrastrukturę, pomoc rozwojową. W systemie klasyfikacji wydatków OECD według funkcji obejmują one również koszty wynagrodzeń pracowników we wskazanych obszarach.

- Inne kategorie wydatkowe, cięcia w ramach tego obszaru dotyczą głównie wydatków funkcjonalnych lub zawieszenia publicznych wydatków inwestycyjnych. Redukcja wydatków w tym obszarze wstępuje we wszystkich planach konsolidacji, realizowanych przez kraje OECD w latach 2009-2015.

Trudno jednak oprócz danych oceniających wpływ proponowanych rozwiązań na deficyt i dług publiczny odnaleźć istotne informacje na temat ich wpływu na sprawność działania państwa w obszarach, gdzie następuje redukcja wydatków publicznych, oraz w konsekwencji na sytuacją makroekonomiczną ${ }^{2}$. Można założyć, że cięcia wydatków nie mają negatywnego wpływu na działanie państwa w sytuacji, gdy zwiększona zostanie efektywność wydatkowania, w przeciwnym wypadku może nastąpić zmniejszenie sprawności niezależnie od tego, czy jest dokonywana analiza efektywności. Brak tej analizy występuje często w sytuacji, gdy za cel nadrzędny uznano zmniejszenie deficytu. Istnieje jednak możliwość połączenia ze sobą zmian w polityce fiskalnej (nawet w przypadku gdy niezbędna jest redukcja wydatków publicznych) z podniesieniem sprawności działania państwa. Dobrym przykładem jest tu Strategia dla Polski, opracowana na lata 1994-1997 (Kołodko, 1994), która była pierwszym kompleksowym dokumentem zawierającym nie tylko ambitny program rozwoju społeczno-gospodarczego, ale także usystematyzowaną wizję restrukturyzacji finansów publicznych. Strategia dla Polski - obok wątków makroekonomicznych i silnego akcentu na budowę instytucji niezbędnych społecznej gospodarce rynkowej - zawierała aż 14 tzw. programów węzłowych dotyczących różnych sfer gospodarki i reform strukturalnych. Każdy z tych programów zawierał w sobie wskaźniki - kryteria wykonawcze, przyjęte dla bieżącego monitorowania ich wdrażania. Strategia dla Polski oparta była na długookresowej koncepcji zrównoważonego rozwoju przy podniesieniu sprawności działania państwa, której priorytetami były:

- szybki wzrost gospodarczy,

\footnotetext{
2 Celem niniejszego artykułu nie jest odniesienie się do wpływu prowadzonych procesów konsolidacyjnych na sytuację makroekonomiczną, niemniej należy zauważyć, że w tej sferze toczy się bardzo ciekawa dyskusja pomiędzy wybitnymi ekonomistami; zob. np. Perrotti, R. (2011). The „Austerity Myth": Gain Without Pain?, BIS Working Paper No 362, IMF Economic Outlook 2010.
} 
- stabilizacja systemowa i makroekonomiczna,

- $\quad$ poprawa warunków życia (Kołodko, 1996).

\section{Czynniki wpływające na sprawność państwa na przykładzie Polski}

Pojęcie sprawnego państwa wymaga uporządkowania charakteryzujących go cech, na potrzeby tego artykułu szczególnie tych, które wiążą się redystrybucją środków publicznych. Współczesne analizy zazwyczaj wykorzystują w tej dziedzinie zakres pojęciowy zbliżony do nauki o zarządzaniu. Obszary charakteryzujące sprawne państwo, szczególnie w kontekście jego efektywności, stanowią kryteria umożliwiające analizę i wartościowanie stanu państwa, jego ocenę jakościową. Przykład takiej systematyki przedstawiono na rysunku 2.

Rysunek 2 | Obszary odziaływania na pojęcie sprawnego państwa

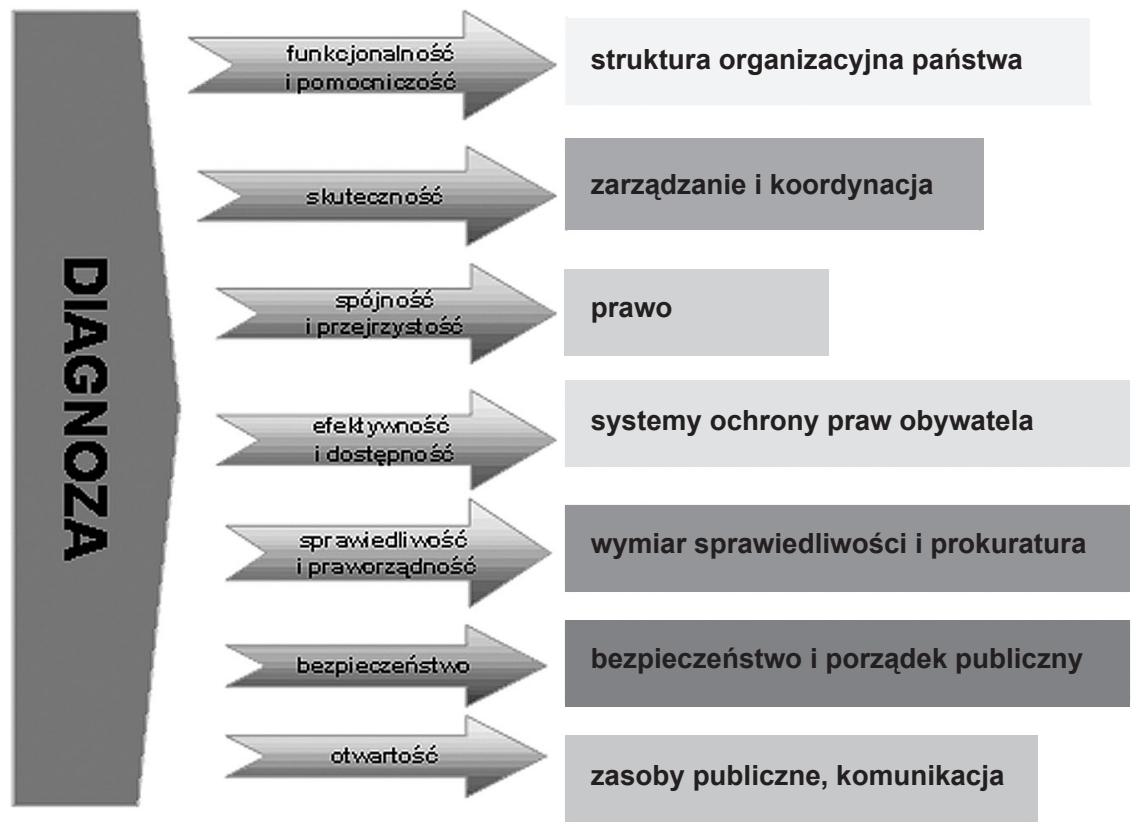

Źródło: Projekt strategii Sprawne państwo 2020, Warszawa, sierpień 2012 r., s. 14.

Zgodnie z zaprezentowanym rysunkiem 2, a także powszechnym rozumieniem pojęcia sprawnych działań, istotny element stanowi funkcjonalność i pomocniczość państwa względem obywateli, częstokroć sprowadzająca się do właściwie uformowanych struktur organizacyjnych państwa i wykorzystywanych przez nie procedur. Funkcjonalność uzależniona jest od sposobu zorganizowania, powiązania istniejących jednostek administracji publicznej i samorządowej oraz treści procedur. Niewątpliwie te elementy i powiązania między nimi zachodzące odgrywają bardzo istotną rolę w kontekście efektywności gospodarowania środkami publicznymi. To właśnie stan organizacji procesów zachodzących w redystrybucji zasobów publicznych ma 
istotny wpływ na osiągnięte rezultaty. W przypadku Polski stan tej organizacji jest efektem zarówno wcześniejszych zmian w procesie transformacji ustrojowej, jak i zmian, które nastąpiły wskutek uporządkowania systemu administracji i dostosowaniu go do rozstrzygnięć Konstytucji RP z 1997 roku. W 1990 roku podjęto kompleksową reformę samorządu terytorialnego. Wprowadzono władzę administracji ogólnej i zasadę zespolenia administracji terenowej; określone zostały działy administracji rządowej z przypisanymi im zadaniami. W 1998 roku zastosowano trójstopniowy podział terytorialny. Stan administracji centralnej w Polsce, m.in. wskutek wielu zmian w strukturze administracyjnej, charakteryzuje się nadmiernym rozczłonkowaniem, często niedookreślonym zakresem odpowiedzialności i w konsekwencji przewlekłością procedur, unikaniem decyzji. Rozbudowane struktury administracyjne skutkują nadmiernymi kosztami, ale co gorsza niskim zaufaniem obywateli do administracji. Jednym z podstawowych czynników wpływających na ocenę sprawności państwa przez obywateli jest efektywność urzędów administracji publicznej. Jest ona przede wszystkim uzależniona od jakości kadry urzędniczej, struktur organizacyjnych, modelu zarządzania i procesu decyzyjnego oraz technik informacyjno-komunikacyjnych. Jasna oraz zrozumiała struktura organizacyjna umożliwia właściwe określenie zakresu i granic kompetencji, tak istotne w świetle realizacji zasady pomocniczości państwa. Takie podejście pozwala częstokrotność na podniesienie efektowności wykorzystania środków publicznych. Dla przykładu w Polsce państwo finansuje zadania związane z polityką rolną ze środków budżetu państwa i poprzez inne jednostki sektora finansów publicznych. Redystrybucja odbywa się bowiem w znacznej mierze za pośrednictwem utworzonych specjalnie w tym celu jednostek sektora finansów publicznych, takich jak: Agencja Restrukturyzacji i Modernizacji Rolnictwa, Agencja Rynku Rolnego, Agencja Nieruchomości Rolnych. Zadania realizowane przez obydwie instytucje częstokroć pokrywają się, a koszty administracyjne ponoszone są przez różne podmioty. Jasne rozgraniczenie realizowanych zadań bądź połączenie obydwu instytucji mogłoby bezdyskusyjnie zwiększyć efektywność wykorzystania środków publicznych ${ }^{3}$.

Drugim elementem oceny sprawności państwa jest skuteczność w zarządzaniu strukturami administracyjnymi i koordynacji ich działań. Jest ona mierzona poziomem realizacji celów stawianych przed instytucjami państwa. Przyjęte cele mogą być osiągnięte całkowicie lub częściowo przez skuteczne działania zarządcze i koordynacyjne. Zakres publicznych działań zarządczych i koordynacyjnych jest nadzwyczaj obszerny. Z punktu widzenia skuteczności główne obszary zainteresowania państwa dotyczą zarządzania instytucjami publicznymi, zarządzania majątkiem Skarbu Państwa, zarządzania kryzysowego, prowadzenia polityki rozwoju oraz polityki międzynarodowej Polski. Aby państwo było postrzegane jako instytucja skuteczna, zarządzanie we wskazanych obszarach powinno być efektywne i skoordynowane, a decyzje nie epizodyczne, lecz wynikające z przyjętych strategii, wzajemnie kompatybilne oraz spójne horyzontalnie. Poziom jakości zarządzania instytucjami publicznymi jest odzwierciedlony w odczuwanym przez obywateli stanie ich relacji z organami państwa, prostocie procedur przy świadczeniu usług publicznych, efektywnym planowaniu i sprawnym zarządzaniu zasobami publicznymi (budżetowymi, ludzkimi i materialnymi). Istotna pozostaje zdolność do terminowego i skutecz-

3 Zagadnienie to zostało omówione szerzej w artykule: Agencja Nieruchomości Rolnych planowanie finansowe dziś i wyzwania na przyszłość. Zeszyty Naukowe Szkoły Gtównej Gospodarstwa Wiejskiego w Warszawie. „Polityki Europejskie, Finanse i Marketing”, nr 6(55), Warszawa 2011.

Vol. 21, No. 2(121), 2013 
nego reagowania na zmieniające się uwarunkowania i pojawiające się nowe wyzwania. Pożądane pozostaje wykorzystywanie nowoczesnych technologii i praktyk zarządzania. Wskazać tu można wykorzystywanie metod nowoczesnego zarządzania publicznego, m.in. zadaniowej konstrukcji budżetu i wieloletniego planowania finansowego. Dla zarządzania rozwojem kraju kluczowy jest właściwy poziom dokumentów strategicznych, przygotowywanych we współpracy partnerów z sektora publicznego, prywatnego, tzw. trzeciego sektora, spójność oraz kompatybilność strategii i programów z obszaru planowania społeczno-gospodarczego na poziomie centralnym oraz w przekrojach regionalnych i przestrzennych. Powinien istnieć odpowiedni system zarządzania ryzykiem np. w aspektach środowiskowych, społecznych i administracyjnych.

Spójność i przejrzystość działań państwa, odnoszone przede wszystkim do systemu prawa, stanowią trzeci element przyjętej tu systematyki opisu sprawnego państwa. Spójność i przejrzystość procedur administracyjnych, systemu tworzenia i egzekwowania prawa w dużym stopniu wynikają ze stopnia zaawansowania merytorycznego dialogu publicznego wszystkich zaangażowanych podmiotów. Konstytutywny wpływ na jakość systemu prawnego ma proces tworzenia i wdrażania instrumentów regulacyjnych i legislacyjnych. Powyższe procesy oraz późniejsza implementacja i stosowanie decydują o jakości kodyfikacji, innych przepisów prawa zawartych w ustawach i rozporządzeniach oraz aktów prawa miejscowego. Spójności i przejrzystości szkodzą nadmierna inflacja prawa, zawiłość procedur; zjawiska te generują zbędne koszty, ostatecznie hamują tempo wzrostu gospodarczego. Do prawodawstwa zostały wprowadzone nowe regulacje w zakresie techniki przygotowywania przez Radę Ministrów inicjatyw ustawodawczych. Nowe rozwiązanie zaimplementowano w celu urealnienia i usprawnienia procesu długookresowego zarządzania środkami publicznymi. Propozycje te nakładają obowiązek zamieszczania w treści projektów ustaw (również będących nowelizacją obowiązujących przepisów) przyjmowanych przez Radę Ministrów maksymalnego, kwotowego limitu skutków finansowych dla jednostek sektora finansów publicznych, które wynikają z wprowadzenia w życie proponowanych regulacji na okres 10-letni. Dodatkowo nowe regulacje prawne muszą zawierać jeden lub kilka mechanizmów korygujących, polegających na:

- limitowaniu liczby udzielanych świadczeń w zależności od środków przeznaczonych na ten cel w ustawie budżetowej lub

- uzależnieniu wypłat od kryterium dochodowego lub majątkowego albo zmianie kryterium dochodowego lub majątkowego uprawniającego do nabycia świadczeń finansowanych ze środków publicznych, lub

- zmianie kosztów realizacji zadań publicznych wykonywanych na rzecz obywateli ${ }^{4}$.

Mechanizmy korygujące mają umożliwić ograniczenie wysokości wydatków wynikających z projektów ustaw w przypadku przekroczenia (lub przewidywanych zagrożeń przekroczenia) poziomu skutków finansowych przyjętego na dany rok budżetowy.

Przed wprowadzeniem nowych regulacji rozwiązania dotyczące skutków finansowych odnosiły się jedynie do informacji zawartych w uzasadnieniach projektów aktów prawnych.

4 Art. 50a ustawy o finansach publicznych dnia 16 grudnia $2010 \mathrm{r}$. 
Dotychczasowe przepisy nie wywierały odpowiednich skutków prawnych w obszarze finansów publicznych.

Kolejną cechą sprawnego państwa jest jego efektywność i dostępność, dotycząca usług publicznych. Egzekwowaniu powinności państwa w tej dziedzinie służy system ochrony praw obywatela. Poziom usług publicznych bezpośrednio przekłada się na jakość życia obywateli, ale i np. na warunki działalności gospodarczej. Efektywność uzależniona jest od relacji pomiędzy nakładami i wynikami, zaś dostępność wynika ze stanu istniejących systemów, standardów i mechanizmów zarządzania usługami publicznymi. Należy również ocenić kulturę organizacyjną administracji publicznej w aspekcie pozycji klienta i jego potrzeb. Przykładowe zakresy usług publicznych badane pod kątem efektywności i dostępności to m.in. system ochrony zdrowia, system zabezpieczenia społecznego, ochrona praw interesów konsumentów, dostęp do infrastruktury (np. energetycznej, komunikacyjnej, telekomunikacyjnej).

Piąty element z katalogu właściwości sprawnego państwa to sprawiedliwość i praworządność, na których straży pozostają wymiar sprawiedliwości i prokuratura. Sytuacja w tym obszarze w szczególny sposób wpływa na zaufanie obywateli do państwa i porządek życia publicznego. Skuteczne funkcjonowanie wymiaru sprawiedliwości uzależnione jest od poziomu regulacji prawnych, stosowanych procedur, stanu i poziomu zawodowego reprezentantów zawodów prawniczych, polityki penitencjarnej, ale również odpowiedniej bazy lokalowej i nowoczesnych technologii.

Kolejnym element opisu nowoczesnego państwa dotyczy bezpieczeństwa. Utrzymanie wysokiego poziomu bezpieczeństwa wewnętrznego i porządku publicznego jest warunkiem koniecznym dla sprawnego funkcjonowania państwa i rozwoju gospodarczego. Uporządkowanie kolejnych opisywanych cech w dużym stopniu nie jest przypadkowe. Zastosowana kolejność jest charakterystyczna dla państw demokratycznych, dla których stan bezpieczeństwa i porządek publiczny jest istotny i równie ważny dla jego przetrwania jak inne opisywane elementy. W przypadku państw totalitarnych lub nie w pełni demokratycznych bezpieczeństwo było (i jest) stawiane ponad innymi zadaniami państwa. W systemach niedemokratycznych w przypadku badania sprawności państwa cecha powyższa przysłaniała wszystkie pozostałe elementy. Dla państwa demokratycznego sprawne i współdziałające ze sobą służby państwowe, operujące w zakresie zwalczania przestępczości i innych zagrożeń dla państwa i społeczeństwa, ograniczają straty społeczne i gospodarcze z tytułu wszelkich zjawisk negatywnych. Służby powinny zapewniać szybką i profesjonalną reakcję w sytuacjach łamania prawa. Istotny jest również odpowiedni poziom zaufania społecznego do służb, przejawiający się we współdziałaniu z nimi lokalnych społeczności. Skuteczne działania służb powinny dać rezultat w postaci wzrostu poczucia bezpieczeństwa obywateli i niskiego poziomu zagrożeń dla państwa i społeczeństwa.

Ostatnim elementem charakteryzującym sprawne państwo jest otwartość jego instytucji, przejawiająca się w dostępności zasobów publicznych i stanie form komunikacji pomiędzy państwem i obywatelem. Otwartość polega na zapewnieniu warunków dla uczestnictwa obywateli w procesie rządzenia oraz możliwości wykorzystywania zasobów sektora publicznego przez obywateli. 
Wraz z przyspieszonym rozwojem nowych technik wymiany informacji następuje demokratyzacja stosunków zastępująca wcześniejszy hierarchiczny sposób porozumiewania się. Instytucje i zwyczaje wynikające z demokracji przedstawicielskiej mogą być rozszerzane bezpośrednio o demokrację partycypacyjną i zaangażowanie obywateli w proces tworzenia usług publicznych. Zmiany technologiczne umożliwiły proste i tanie udostępnianie informacji publicznych, tworzenie i udostępnianie otwartych zasobów publicznych. Komunikacja i współpraca pomiędzy instytucjami publicznymi, a także obywatelami, może być nawet skrajnie transparentna. Nowe wyzwania stoją przed procesami konsultacji społecznych, przy czym pewnym kłopotem pozostaje nadmiar możliwości i brak zainteresowania obywateli w tych procesach.

\section{| Co może połączyć politykę konsolidacji fiskalnej ze sprawnie działającym państwem?}

Próbując znaleźć odpowiedź na tak postawione pytanie, warto zwrócić uwagę, że kompleksowy i obowiązkowy system ewaluacji wydatków stanowi element zarządzania budżetem Unii Europejskiej, natomiast już dyrektywa w sprawie ram budżetowych krajowych nie obejmuje tego rozwiązania w żadnym zakresie. Systemy ewaluacji wydatków publicznych stanowią nadal domenę rozwiązań krajowych. W tym elemencie można dostrzegać przyczyny słabości w dotychczasowej implementacji Paktu Stabilności i Wzrostu.

W ostatnich latach w wielu krajach krytyczna ocena stanu finansów publicznych zmusiła władze publiczne do prowadzenia pozornie sprzecznych działań, prowadzących do przywrócenia równowagi fiskalnej oraz powrotu gospodarki na ścieżkę wzrostu gospodarczego.. Wskazać tu należy działania na rzecz poprawy efektywności sektora publicznego, m.in. przez rewizję i usprawnienie procedur zarządzania finansami publicznymi. Celem zmian miało być powstrzymanie narastania zjawisk kryzysowych, konsolidacja finansów publicznych i przywrócenie zdolności skutecznego realizowania obranych celów polityki fiskalnej. W ramach sporządzonego przez OECD przeglądu tych działań wyspecyfikowano główne obszary zmian: wprowadzenie średniookresowych prognoz budżetowych, wykorzystanie ostrożnych założeń i prognoz makroekonomicznych, zastosowanie w budżetowaniu procesów top-down, ograniczenie centralnego sterowania wydatkami przy zwiększeniu odpowiedzialności jednostek sektora i wykorzystaniu nowoczesnych metod zarządzania, przejrzystość procesów planowania i wykonywania budżetów oraz ukierunkowanie na efekty (OECD 2011, s. 2). Ostatni wskazany, lecz zapewne kluczowy obszar zmian w zarządzaniu finansami publicznymi, dotyczy skierowania szczególnej uwagi na rezultaty i efektywność działań. Zespół metod budżetowania uwzględniający pomiar efektywności jest określany jako budżet zadaniowy. Zakres i stan zaawansowania budżetu zadaniowego jest bardzo zróżnicowany w poszczególnych krajach. Nie istnieje konsensus w sprawie określenia optymalnej drogi wykorzystania w budżetowaniu oceny efektywności. Główną przyczyną jest w tym przypadku brak możliwości standaryzowania struktury celów i zadań oraz niewielka możliwość wykorzystywania doświadczeń międzynarodowych w tej dziedzinie. Problemy wynikają przede wszystkim z faktu, że niektóre zadania nadają się do pomiaru łatwiej niż inne, rezultaty zaś są często trudne 
do określenia. Występuje rozbieżność między przedmiotem pomiaru a tym, co w rzeczywistości jest możliwe do zarządzania. Trudna do uzyskania jest pożądana niezawodność i spójność danych o rezultatach. Problemy stwarzają również sposoby reakcji na niedostateczną w stosunku do zaplanowanej efektywność. Według wcześniejszych badań (OECD, 2011, s. 34), których wyniki opublikowano w 2011 roku, 29 (spośród 33 badanych) krajów OECD przy analizie stopnia realizacji wydatków publicznych (programów) wykorzystuje informację o produktach (ilość, jakość i wartość towarów i usług publicznych) i rezultatach (wpływ na wskaźniki społeczno-ekonomiczne). W 24 krajach stosowane są syntetyczne mierniki dotyczące produktów i rezultatów, zaś w 12 krajach prezentowane są inne formy informacji o niefinansowych efektach działań instytucji publicznych. Odpowiedzi na dalej idące pytanie (OECD, 2011, s. 39) zawarte w badaniu, dotyczące sposobu wykorzystania informacji efektywnościowej przez administrację publiczną, wskazują jednak na ograniczone zastosowanie tych informacji. Więcej niż połowa badanych krajów (19) wykorzystuje informację efektywnościową do uzasadnienia istniejącej alokacji środków, w 18 krajach jest ona wykorzystywana do ustalania celów i zarządzania programami, 15 krajów wskazało na użyteczność przy rewizji działań. Bezpośredni wpływ danych o efektywności na alokację nakładów publicznych zadeklarowano w mniejszości badanych krajów OECD. W 12 przypadkach wskazano możliwość zmian wewnątrz programów, w 10 wpływ na alokację pomiędzy programami, zaś tylko w 9 wpływały na ograniczenie wydatków. Badanie potwierdza pogląd, że ocena efektywności wykorzystywana jest w zarządzaniu programami publicznymi, nie stanowi jednak decydującego kryterium przy alokacji środków publicznych, czyli w budżetowaniu.

\section{Rysunek 3 | Logika interwencji budżetu zadaniowego}

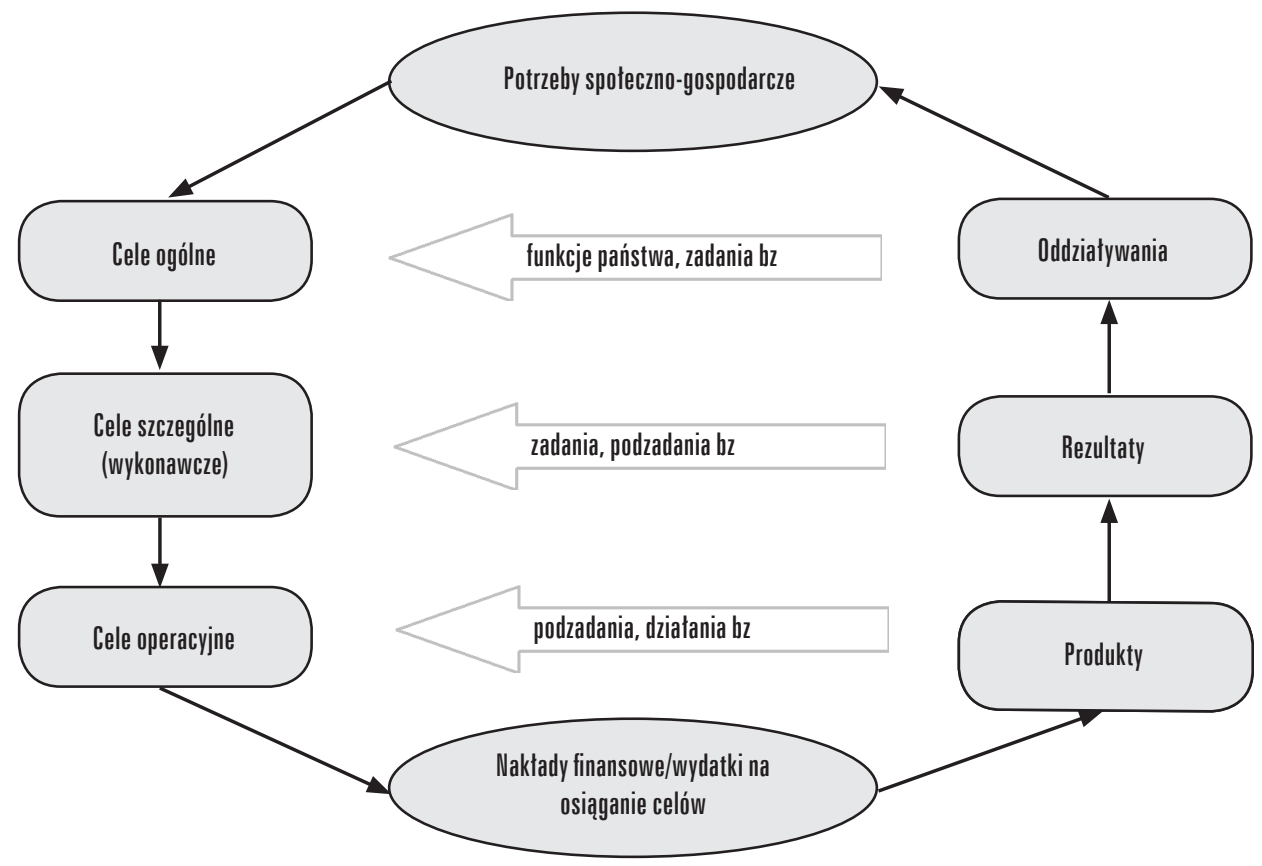

Źródło: Ministerstwo Finansów, www.mf.gov.pl. 
Wykorzystywanie w budżetowaniu podstawowych elementów budżetu zadaniowego, tj. określenia celów, rezultatów i efektywności działań, zmienia logikę klasycznego procesu budżetowego. W klasycznej sytuacji istotna była realizacja tytułu wydatkowego (czy zadanie zrealizowano, czy też nie) i możliwie maksymalne wydanie środków finansowych (w potocznym rozumieniu środki zapisane w budżecie i nie wydane przepadają, a więc z punktu widzenia konkretnego podmiotu realizującego budżet są zmarnowane). Uzupełnienie procesu budżetowego o system oceny efektywności i skuteczności zmienia powyższą sytuację. Z prostej zależności: tytuł wydatkowy - środki finansowe - realizacja powstaje nowy układ tworzący nową logikę interwencji budżetu zadaniowego, zaprezentowany na rysunku 3.

\section{Podsumowanie}

Wiarygodna i skuteczna polityka fiskalna jest jednym z elementów polityki gospodarczej prowadzącej do osiągnięcia stabilnego i zrównoważonego rozwoju danego kraju. Na politykę fiskalną składa się wiele działań poszczególnych rządów, których wzorce zostały wypracowane przez dziesiątki lat rozwoju teorii ekonomii, nauki o finansach, jak też zarządzania publicznego. Optymalna polityka fiskalna powinna wykorzystywać dobrze dobrane narzędzia pozwalające na osiągnięcie maksymalnie dobrego sposobu gospodarowania środkami publicznymi w danym otoczeniu zewnętrznym i wewnętrznym, w jakim znajduje się dana gospodarka. Czynnikiem decydującym o sprawności państwa (pomijając czynniki pozafinansowe) nie są absolutne i względne rozmiary wydatków publicznych. Poziom sprawności jest uzależniony od struktury tych wydatków oraz procedur związanych z procesem planowania, realizacji, ewidencji i sprawozdawczości dotyczącej wydatków publicznych, jak też poziomem systemu oceny efektywności i skuteczności. Efektywne zarządzanie środkami publicznymi powinno spełniać nie tylko jedno kryterium, tzn. osiągnięcie jak najlepszego wyniku sektora finansów publicznych w krótkim czasie, ale powinno wiązać się z długofalowym spojrzeniem na sprawność działania państwa.

\section{B i b l i 0 c g r}

Kołodko, G.W. (1994). Strategia dla Polski. Warszawa: Poltext.

Kołodko, G.W. (1996). Polska 2000. Strategia dla przyszłości. Warszawa: Poltext.

Kaufmann, D., Kraay, A. i Mastruzzi M. (2010). The Worldwide Governance Indicators: Methodology and Analytical Issues, Washington DC, September 2010, World Bank Policy Research Working Paper No. 5430.
OECD (2011). Budgeting Features that Strengthen Fiscal Policy in OECD Countries. Results from the OECD Budget Practices and Procedures Database. Draft report. Paris.

OECD (2012). Restoring Public Finance. Paris.

Owsiak, S. (2000). Finanse publiczne. Teoria i praktyka. Warszawa: Wydawnictwo Naukowe PWN.

Peacock, A.T. i Scott, A. (2000). The Curious Attraction of Wagner's Law. Public Choice, 102. 